\title{
An Analysis of Women's Social Position in Early 20th Century from The Sound and the Fury
}

\author{
Yang Zhao \\ Foreign Languages College, Beihua University, Jilin 132013, China.
}

Keywords: William Faulkner, The Sound and the Fury, social position.

\begin{abstract}
The Sound and the Fury is the fourth novel of the representative figure of stream of consciousness literature in the United States, which is also William Faulkner's masterpiece. This novel, in a unique narrative way, tells the tragedy of a decline of the southern family-the Compson's family, in which there is enough despair and nihilism but not much love and emotion. The current domestic research mainly focuses on the narrative angle and the time view, while the foreign research mainly focuses on the world of women in plantation, so there is little research on the women's social position on that time. This paper attempts to analyze the social position of American women in early $20^{\text {th }}$ century, from the view of main female figures, including Carry, Carry's mother Mrs. Compson, and their maid Dilsey.
\end{abstract}

\section{Introduction}

William Faulkner is one of the most influential writers in the history of American literature. He is the representative figure of stream of consciousness literature in the United States. He won the Nobel Prize in 1949 because he has made a strong and unparalleled contribution to contemporary American novel. Faulkner who was born into a Southern family with a fairly long tradition is perhaps the most important of all the influences that made him what he became: a major writer in American literature.

His full-length novel, The Sound and the Fury, tells a story of deterioration from the past to the present. The past is idealized to from a striking contrast with the loveless present. There is in an acute feeling of nostalgia toward the happy past. Quentin's section offers a good illustration. A miserable creature in the modern world, Quentin frequently casts a backward glance at the time of his childhood when life was innocent, romantic, and secure. He just cannot bring himself to come to terms with the present which is, to him, purposeless, futile, and devoid of the values. His suicide offers an example of a complete negation of the present. In a sense, Quentin's value system may represent Faulkner's own idea of an idea way of life, that of an antebellum society. The fact that Benjy's section begins the book is not a haphazard arrangement on the part of the author, for it is Benjy who feels most keenly the loss of love. Benjy lives on the emotional support of love. Although an idiot with no sense of time, he knows who loves him best. When Caddy is gone, his world of love vanishes with her; and nobody can take her place, not even Dilsey. Thus, this section helps to dramatize the theme of loss from the very beginning of the story. With the story of Jason whose life embodies all the vices of the modern world, the contrast between the ante-bellum society and the present one is brought out in the most poignant manner possible. The triumph of rationalism over feeling and compassion is best illustrated in this sterile and loveless individual.

\section{Caddy's tragedy}

Caddy is the central character in this novel and she is pitiful. Faulkner shows special preference to her, he said "I love her so much, I think only writing a short story of her life is not enough, her story should be longer than that short story." Caddy is the only daughter of the Compsons family. She is beautiful, warm, compassionate, especially she treats the vulnerable groups with full of love, understanding and care. We can see the good of humanity on her. Caddy has all kinds of advantages 
that Faulkner thinks the southern should have. She is so kind that she treats Jason gently even he asks her for money.

Caddy's kindness, bravery and honesty make her the loveable image of women in Faulkner's novels. She was born in a declining southern noble family-the Compsons. The Compsons still adhere to the traditional ethics, restrict Caddy's freedom roughly and interfere in her development. Due toher family's indifference, force and stress, Caddy feels extremely lonely. She can't find love in their home, her mother is selfish and indifferent, she blames everything but herself all day; Benjy only knows to ask for her love; Quentin holds the old southern tradition and destroys Caddy and Dalton's love selfishly. Caddy has no choice but to go outside to look for love, eventually, she turns her way to a degrading way that she has a lot of lovers. She gets pregnant before getting married, and even doesn't know who the father of her child is. After being evicted from her home, she becomes a prostitute, she finally descends into the Nazi officer's mistress.

Through shaping the image of Caddy, Faulkner describes such a decline in the South, life is surrounded by deep-rooted sense of male power. In order to grasp the domination of women firmly, a strong patriarchal system under the guise of maintaining the traditional tradition of the South not only deprives of their right to speak, but also sets an unfair moral ethics. That forces them to abide by the morality, so women are completely lost as a person's dominant position. From Quentin, Benjy, and Jason's reaction to Caddy's loss, it can be seen that men's possession and slavery. The first manifestation is their morbid worship to female chastity. For male elements, the woman's value lies only in her virgin; its importance is far more than a woman's life. In order to ensure the purity of women and imprison them in the chastity forever, men strangle their physiological desire, deprive of their voices, and obliterate their natural rights.

Thus, by describing Caddy's heartbreaking story from the "most beautiful" to the cursed "whore" tragedy, Faulkner relentlessly exposed the old traditions of the South, including the chastity of the south and the destruction and persecution of women. Most of the women in the form of Caddy as the representative are ended of tragedy. It is not Faulkner's feminist concept at work, but because he said, in his career, the only thing to do is humiliating the United States, criticizing the United States and trying to show the difference between its evil and kindness ... telling the people the evil side of things, so that they can be ashamed and angered. That is the only way they can change those evil things.

\section{Mrs. Compson's tragedy}

Mrs. Compson is poisoned by the patriarchal society, she grew to be an ideal "lady", and convinced that virginity was the most important thing for a "lady". She uses the "lady standard" to restrain herself and tries to persuade everyone around. From all the aspects, she is a typical southern lady. After her husband's death, Mrs. Compson is always lying in bed, and lets her son Jason to manage the whole family and make important choices. Meanwhile, Mrs. Compson has no female consciousness, and can't resist the patriarchal society standard for ladies. Mrs. Compson is a representative of the southern "lady", but she is only a victim of the southern lady tradition. Her marriage is not happy, but she has no courage to divorce with Mr. Compson. Since Mr. Compson is an alcoholic, there is few support and thoughtfulness between them. In her life, her son Jason and her brothers are always more important than Mr. Compson. On the other hand, she instills her daughter Caddy with the dogma and standards of patriarchal society. That makes Caddy to be another victim. At the age of 15, Caddy kissed a boy for the first time out of curiosity, which seemed to be outrageous to Mrs. Compson. It is completely deviant from "the Southern lady view" represented by Mrs. Compson. She not only does not give Caddy any guide but also sends Jason to monitor Caddy, and forbids her to interact with boys. When her family find that Caddy has fell in love with Dalton and pregnant, Mrs. Compson takes Caddy toa vocation to avoid the rumor, and takes the opportunity to find a husband for Caddy to avoid damage of the family's reputation. Mrs. Compson breaks her daughter's happiness and Caddy lost her first love. Mrs. Compson is narrow and selfish, she changes the name of Benjy to reduce her responsibility of giving birth to the retarded son. In her view, the birth of Benjy is God's punishment 
for her. She decides to change the kid's name from Maule to Benjy because she tries to reduce the connection between Benjy and Compson family. It is clear that she does not care about her son. Although Benjy does not understand what his mother does, he has the ability to identify the love and warmth from his sister Caddy. If he could identify who his mother is, he might say Caddy's name.

\section{Dilley's tragedy}

In the novel with gloomy atmosphere, Dilsey can be said to be a woman with love, intelligence, honesty and closed with nature. Faulkner said: "Dilsey is one of my favorite characters because she is brave, bold, generous, gentle and honest." When she wrote for the novel's "Introduction", he said: "Dilsey on behalf of the future."She is a symbol of renascence and life. Although she is only a black maid, she is loyal, loving, strong and patient and has other virtues of the incarnation what is advocated by Faulkner. She gives her care unreserved to the people around and has no regrets taking care of selfish and apologetic Mrs. Compson. She also takes care of Caddy and her brothers who are lack of maternal love.

She treats others from her good nature. She cares and takes care for Benjy. She is not afraid of the host's hatred and secular discrimination and protects the weak bravely. When Jason abuses Miss Quentin, she comes forward. Particularly commendable is that, although she is a servant, she dares to oppose Jason's evil and direct his ruthless. Faulkner once said that because Dilsey was selfless, even Jason was conceived to her.

Although Dilsey belongs to the bottom of society, she represents the highest quality of human beings in the society. She becomes a symbol of dignity and patience of human beings because of struggling in the life indomitably. She serves herself in the life of the Compson family and witnesses the whole process of the Southern part of the old from the prosperity to the decline, like a pillar of the shaky door. The old tradition of power on behalf of the old system will collapse, become over the clouds. As Dilsey said, she saw the beginning, also saw the end. And Dilsey represents the future. She makes a positive and optimistic response to their own personality. Her patience, toughness, integrity and good character is also a symbol of the future, representing the hope of the rebirth of the South society.

\section{Conclusion}

The creating background of The Sound and the Fury is after the Civil War, the South experienced a profound historical change. The feminine view of the devoid women, which is based on the agricultural production methods, racism and Puritanism in the South, is also the view of chastity, which is falling apart with the destruction of traditional cultural values and living habits. Faulkner, by shaping the ladies Caddy and Mrs. Compson, fiercely attacked the persecution of the traditional women's view and the deforming Puritan thought on the Southern women; by showing the part of the little Quentin, under the yoke of the women's resistance and protest; finally, through the black female slave Dilsey's character to promote the South to regain the traditional virtues and the return of human nature.

Faulkner succeeded in describing the process of an old aristocratic plantation went to decline and death with an innovative stream of thought. The reader was more clearly drawn from Women's tragedy: in early $20^{\text {th }}$ century, women enjoyed very little economic, political and educational rights; their social status cannot be compared with the men, they were subject to male domination and lack of social respect. At present, the social status of women has improved in many aspects, but some women still do not get fair treatment. Therefore, we should always pay attention to women's social status in order to protect their legitimate rights and interests, no matter in the past or in modern society, we believe that cooperation based on socio-economic principles would respect the rights of women. 


\section{References}

[1]. Adams, Richard P. Faulkner: Myth and Motion [M]. Princeton University Press, 1968.

[2]. Brooks, Cleanth. William Faulkner: The Yoknapatawpha County [M]. Yale University Press, 1963.

[3]. Fiedler, Leslie. Love and Death in the American Novel [M]. Criterion, 1966.

[4]. Howe, Irving. William Faulkner: A Critical Study [M]. Random House, 1952.

[5]. Rubinstein, Annette T. American Literature Root and Flower [M]. Foreign Language Teaching and Research Press, 1998. 